\title{
Age of Information
}

Age of Information:

Basic Concepts and Its Theoretical Analysis

井上文彰 Yoshiaki INOUE

滝根哲哉 Tetsuya TAKINE

アブストラクト リアルタイム性を重視するモニタリングシステムでは, 常に最新の情報をモニタに表示することが肝要である ため, 古くなった情報は極めて低い価值しか持たない，すなわち，取得からの時間経過に伴って情報の価值は減衰してゆ き，適切な頻度で情報更新がなされない限り，モニタが表示する情報はほとんど無価値になってしまう．従来，このような システムに対する代表的な性能評価指標として遅延時間が用いられてきたが，これは情報の鮮度を保つという観点ではあく まで間接的な指標にすぎない. Age of Information (Aol) は, 情報の鮮度を直接的に定量化する新しい指標であり, 過去数 年の間に Aol に関する研究は大きな広がりを見せている. 本稿では, Aol の基本概念を解説し, 更にその理論的解析法, 並 びに理論的結果から導かれる Aol の制御に関する基本的な考え方を紹介する.

キーワード Age of Information, モニタリングシステム, 標本路解析, 待ち行列理論

Abstract For real-time monitoring systems, the primary performance objective is that sufficiently fresh information is displayed on monitors. As a result, information with an old timestamp has little value in such systems. In other words, the value of information decreases as time passes, and displayed information can be useful only if it is updated frequently enough. Although the delay of packets with new information has conventionally been used as a representative performance metric for monitoring systems, it is an indirect measure of information freshness. The age of information (Aol) is a new metric that quantifies the freshness of information directly, and considerable research efforts on it have been expended recently. In this article, we first introduce the basic concept of the Aol. We then present a mathematical basis for the theoretical analysis of the Aol, and we demonstrate its usefulness by providing some insights obtainable from theoretical results into the control of the Aol performance.

Key words Age of Information, Monitoring Systems, Sample-Path Analysis, Queueing Theory

\section{1.はじめに}

エレクトロニクス技術の飛躍的な進歩に伴い，近年，無線通 信機能を搭載した安価な小形センサ機器が急速に普及しつつあ る. Internet of Things (IoT) は，このようなセンサ機器を利 活用し，大量かつ多様な情報の収集，集約，並びに処理を行う 情報システムの総称であり，工場や商業店舗をはじめ，病院，農 地，並びに屋外施設など，非常に多岐にわたる場面において変 革をもたらすことが期待されている．IoT の最も主要なアプリ ケーションの一つが, 遠隔地からの「状態モニタリング」であ る。例えば，工場におけるラインの監視や農地における作物の 生育チェックなどは，時間変化する対象の状態を常時モニタリン グするシステムである．状態モニタリングを行うシステムでは

井上文彰 正員 大阪大学大学院工学研究科電気電子情報工学専攻 E-mailyoshiaki@comm.eng.osaka-u.ac.jp 滝根哲哉 正員 大阪大学大学院工学研究科電気電子情報工学専攻 E-mail takine@comm.eng.osaka-u.ac.jp Yoshiaki INOUE and Tetsuya TAKINE, Members (Graduate School of Engineering, Osaka University, Suita-shi, 565-0871 Japan). 電子情報通信学会 基礎・境界ソサイエティ

Fundamentals Review Vol.13 No.3 pp.197-208 2020 年 1 月 C電子情報通信学会 2020
通常，実際の状態よりも古い情報がモニタに表示されることに なる。なぜならば，センサは多くの場合バッテリー駆動である ことから, 省電力化のため, 状態の計測は間隔を空けて断続的 に行われるためである。加えて, 遠隔地のセンサからモニ夕ま で観測デー夕を伝送し，そのデータを処理する際に通信遅延や 処理遅延が生じる.

このようなシステムの設計を考える上で最も基本となる検討 事項は，モニ夕に表示される情報はどの程度の鮮度を有してい るのかということである。この観点から, 最近, 提案された性 能指標が Age of Information (AoI) (1)，(2)である. AoI は，モ ニ夕に現在表示されている情報がセンサにより取得された時刻 (タイムスタンプ) と現時刻との差で定義される量であり, モニ タリングされている情報の鮮度そのものを定量化している．AoI は非常に基礎的な概念であり，かつ，IoTによる状態モニタリ ングをはじめとする，様々なモニタリングシステムの設計にお いて中心的な役割を果たす量でありながら, 近年まで長らく研 究者らから見落とされてきたものである。

過去数年間のうちに，AoI に関する研究は加速度的に進展し ており，既に多数の研究論文が報告されている(3). 本稿は, AoI 研究を理解するための導入として, AoI の基本概念並びにその 理論的解析法の基礎的事項を解説することを目的とする. 


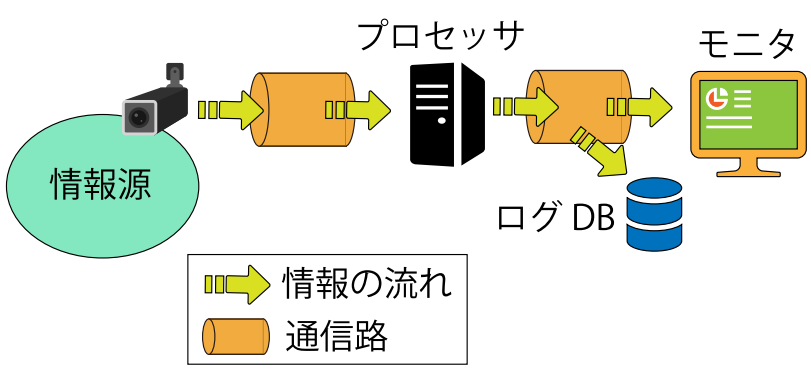

図 1 モニタリングシステムの模式図

以下の本稿は次のように構成される，2.では，AoI の定義を 述べ, AoI から派生する各種性能指標を導入する。更に，単純な 遅延時間と AoI との違いについて説明する．3.では，モニタリ ングシステムの性能評価に扔けるAoI が占める役割の具体例と して，モニタリング対象がウィーナー過程あるいは連続時間マ ルコフ連鎖で定式化される場合に得られる結果を紹介する４． では, AoI に対する理論解析の出発点として, 標本路上での単 純な観察から, AoI の確率分布や平均值に関する一般的な公式 が得られることを示す．5.では，この公式の適用例として，幾 つかの基本的な確率モデルに対する解析結果を示す. 6. では, サンプリング間隔並びに処理順序の観点から AoI の制御に関す る基本的な考え方を提示する．7．では，AoI に関する既存研究 を紹介し，最後に8.に拈いて本稿を締めくくる.

\section{Aol の定義}

本稿では説明を簡単にするため, 図 1 で模式的に表現される モニタリングシステムに焦点を当てる。このシステムでは時間 変化する情報源がある頻度で観測 (サンプリング) され，得られ た情報は通信路を介してプロセッサに転送される。プロセッサ は受信したデータに対し処理を施すことで，サンプリング時点 に抢ける情報源の状態を抽出する。この状態情報は更に通信路 を介してモニタとログデータベース（ログ DB）に転送され，モ ニタの表示を更新するとともにログ DB に格納される.

1.で述べた IoT センサによるモニタリングシステムは上記の 模式図で表されるシステムの一例である。このようなシステム はほかにも数多く存在するが，ここでは以下の三つを挙げる.

例 1 (コネクテッドカー $\left.{ }^{(1)}\right)$. コネクテッドカーは, センサやカ メラにより車両や道路の状態を観測し，更にその情報を周囲の 車両と共有することで，リアルタイムに自身や周囲の環境をモ ニタリングし，運行の安全性の向上に活用する．周囲の車両か ら受信する情報に注目すると, 送信元車両の観測対象が図 1 に おける情報源, 送受信車両間の無線通信ネットワークが通信路 に相当する。

例 2 (リアルタイム映像解析). 顔認識や物体識別など，機械学 習技術を用いて監視カメラ等の映像からリアルタイムに情報を 抽出するシステムが実用に供され始めている。このようなシス テムでは，カメラの撮影対象が図 1 に打ける情報源，エッジあ るいはクラウドに配置された計算機がプロセッサ，それらの間 をつなぐ通信ネットワークが通信路に相当する。

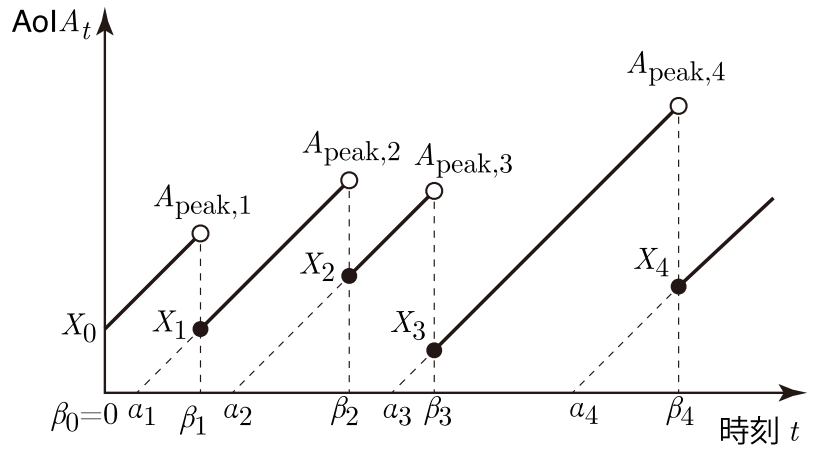

図 2 Aol 過程 $\left\{A_{t}\right\}_{t \geq 0}$ の例

例 3 (クラウドゲーミング $\left.{ }^{(4)}\right)$. クラウドゲーミングは, ゲーム の演算や画面のレンダリングをクラウドサーバにオフロードす ることでスマートフォン等からでも高機能なゲームを実行可能 にする技術である。サーバはユーザからの入力を基に内部状態 を更新し，ゲームの映像フレームを生成してユーザにストリー ミング配信する，クラウドゲーミングは，サーバの内部状態が 図 1 に扔ける情報源，ユーザの端末がモニ夕に相当するモニ夕 リングシステムとみなすことができる.

AoI は, モニ夕に表示されている情報の鮮度を表す指標であ り, 表示中の情報のタイムスタンプと現時刻との差で定義され る.すなわち, 時刻 $t(t \geqq 0)$ においてモニ夕に表示中の情報の タイムスタンプを $\eta_{t}$ とすると, 時刻 $t$ における AoI $A_{t}$ は

$$
A_{t}=t-\eta_{t}, \quad t \geqq 0 .
$$

で与えられる，定義から，AoI の值が小さいほど情報の鮮度は 高いことが分かる. また, $\left\{\eta_{t}\right\}_{t \geqq 0}$ は情報更新の発生から次の 情報更新の発生までの間は一定值を取り, 情報更新の時点にお いて増加 (上向きにジャンプ) する区分的定数関数である。した がって, AoI $\left\{A_{t}\right\}_{t \geq 0}$ は図 2 に示すようなのこぎり歯状の区分 的線形関数として表される.

このように, AoI は時刻の関数 $\left\{A_{t}\right\}_{t \geqq 0}$ として表現される 連続時間過程である。したがって, AoI を用いてシステムの性 能評価を行うためには $\left\{A_{t}\right\}_{t \geqq 0}$ の集計值 (すなわち, $\left\{A_{t}\right\}_{t \geqq 0}$ に汎関数を作用させた結果) を用いる必要がある. AoI 過程の集 計值として最も広く用いられているのは，その時間平均

$$
m_{A}^{\sharp}:=\lim _{T \rightarrow \infty} \frac{1}{T} \int_{0}^{T} A_{t} \mathrm{~d} t
$$

である. AoI の時間平均 $m_{A}^{\sharp}$ は AoI の大きさを表す基本的な指 標であり，更に，3. で紹介するとおり，情報源をある種の確率 過程として定式化した場合に，モニタリング精度を直接特徵付 ける重要な量となっている.

AoI の時間平均は, 情報の価値が経過時間に対して線形に劣 化することを仮定した場合の「コスト関数」の平均として解釈 することもできる。一般に, 取得から時間 $x$ が経過した情報を モニタに表示するコストを $C(x)(x \geqq 0)$ とすると, 時間平均 コストは次式により定義される。

$$
m_{C(A)}^{\sharp}=\lim _{T \rightarrow \infty} \frac{1}{T} \int_{0}^{T} C\left(A_{t}\right) \mathrm{d} t
$$


よって, $\mathrm{AoI}$ の時間平均 $m_{A}^{\sharp}$ は, $C(x)=x$ という線形コスト 関数に対する時間平均コストとみなすことができる．多くの場 合，情報の価值は非線形に減少する (例えば，始めは急激に価值 が減少し，価值が十分に下がった後の変化はなだらかになるな ど）と考えるのが自然であり，その場合，非線形コスト $C\left(A_{t}\right)$ $(t \geqq 0)$ の時間平均が興味の対象となる.

更に，AoI 過程をより詳細に特徴付ける集計值として，AoI の漸近頻度分布 ${ }^{(5)} A^{\sharp}(x)(x \geqq 0)$ がある. $A^{\sharp}(x)$ は AoI 過程が $x$ 以下にとどまっている時間割合を表し, 次式で定義される.

$$
A^{\sharp}(x)=\lim _{T \rightarrow \infty} \frac{1}{T} \int_{0}^{T} \mathbb{1}\left\{A_{t} \leqq x\right\} \mathrm{d} t
$$

ただし， $\mathbb{1}\{\chi\}$ は事象 $\chi$ の指示関数である. 漸近頻度分布 $A^{\sharp}(x)$ $(x \geqq 0)$ を用いることで, AoI 過程の平均まわりのばらつきの大 きさなど, 時間平均 $m_{A}^{\sharp}$ だけでは捨象されてしまう AoI の特徵 付けを行うことができる。特に，漸近頻度分布 $A^{\sharp}(x)(x \geqq 0)$ が与えられたとき, 任意の非線形コスト関数 $C(x)$ に対する時 間平均值 $(2)$ は次式で求められる.

$$
m_{C(A)}^{\sharp}=\int_{0}^{\infty} C(x) \mathrm{d} A^{\sharp}(x)
$$

この意味で，漸近頻度分布 $A^{\sharp}(x)(x \geqq 0)$ は AoI 過程を詳細に 特徵付けるための基本的な量となっている.

理論的解析においては, AoI 過程 $\left\{A_{t}\right\}_{t \geq 0}$ を決定論的過程と して取り扱うことはまれであり, ほとんどの場合 $\left\{A_{t}\right\}_{t \geqq 0}$ は土 ルゴード的な定常確率過程として定式化される。このとき， $A$ を AoI 過程 $\left\{A_{t}\right\}_{t \geqq 0}$ の定常分布に従う確率変数とすると，工 ルゴード性から上記の性能指標は次式を満たす.

$$
m_{A}^{\sharp}=\mathrm{E}[A], \quad m_{C(A)}^{\sharp}=\mathrm{E}[C(A)], \quad A^{\sharp}(x)=\operatorname{Pr}(A \leqq x)
$$

このほか, AoI 過程 $\left\{A_{t}\right\}_{t \geq 0}$ から求まる性能指標として, ピーク AoI ${ }^{(6)}$ と呼ばれる量が用いられている。ピーク AoI は 情報更新が発生する直前における AoI $A_{t}$ の值として定義され， 図 2 ののこぎり歯のピークの点を表す。ピーク AoI の平均值 は簡単な公式を用いて求めることができる. 更に, 多くの場合, $\mathrm{AoI}$ の時間平均 $m_{A}^{\#}$ に対する上界を与えることから，しばしば 代替的な性能指標として利用される.

従来，モニタリングシステムにおける代表的な性能指標とし て用いられてきたのはシステム遅延，すなわち，情報源がサンプ リングされてからモニ夕の情報が更新されるまでに要する時間 である，定義から，モニ夕の表示が更新された直後の時点にお ける AoI は，この最新の情報パケットのシステム遅延に等しい. 図 2 から明らかなように, AoI 過程を再現するためにはシステ 厶遅延に加えてモニ夕表示の更新間隔を知る必要がある。この 意味で，情報の鮮度が重要なシステムにおいては，システム遅 延は不十分な性能指標であることが分かる.

\section{Aol とモニタリング精度}

本章では，情報源が確率過程として定式化される場合を考える. $Z_{t}(t \geqq 0)$ を時刻 $t$ における情報源の状態とし, $\left\{Z_{t}\right\}_{t \geqq 0}$ はあ
る状態空間 $\mathcal{S}$ 上の連続時間確率過程をなすとする。一方，AoI 過程 $\left\{A_{t}\right\}_{t \geqq 0}$ は， $\left\{Z_{t}\right\}_{t \geqq 0}$ とは独立な連続時間エルゴード的 定常確率過程として表されると仮定する. $\left\{A_{t}\right\}_{t \geq 0}$ と $\left\{Z_{t}\right\}_{t \geq 0}$ の独立性は，送信側端末が情報源からの観測值 (正常範囲内か否 か等) に応じて動的にサンプリング間隔を決定する場合には成 立しないことに注意を要する。一方，観測值にかかわらず常に AoI の值を小さく保つことを要求されるシステムや， 2. で述べ た例 2 のように，送信側端末からは観測値を知ることのできな いシステムに拈いては，この独立性の仮定は満たされている．

モニタには，最後に受信した状態情報が常に表示されるとす ると, 時刻 $t$ に扔いてモ二夕に表示されている情報源の状態 $\hat{Z}_{t}$ $(t \geqq 0)$ は式 $(1)$ から次式で与えられる.

$$
\hat{Z}_{t}=Z_{\eta_{t}}=Z_{t-A_{t}}
$$

以下では，情報源の状態 $\left\{Z_{t}\right\}_{t \geq 0}$ がウィーナー過程あるいはマ ルコフ連鎖に従う場合, $\left\{Z_{t}\right\}_{t \geq 0}$ と $\left\{\hat{Z}_{t}\right\}_{t \geq 0}$ の「近さ」, すな わちモニタリング精度が平均 AoI $\mathrm{E}[A]$ を用いて特徴付けられ ることを示す。

\section{1 情報源がウィーナー過程に従う場合 $(\boldsymbol{7})$}

$\left\{Z_{t}\right\}_{t \geq 0}$ がウィーナー過程に従う場合を考える. ウィーナー過 程の状態空間は実数全体 $(\mathcal{S}=\mathbb{R})$ であり，時間間隔 $\tau(\tau \geqq 0)$ の 間に生じる変位 $Z_{t+\tau}-Z_{t}$ は平均 0 分散 $\tau$ の正規分布 $\mathcal{N}(0, \tau)$ に 従う。このとき, $\left\{A_{t}\right\}_{t \geqq 0}$ と $\left\{Z_{t}\right\}_{t \geqq 0}$ の独立性並びに $\left\{A_{t}\right\}_{t \geqq 0}$ の定常性から，次式が成立する。

$$
\mathrm{E}\left[\left(\hat{Z}_{t}-Z_{t}\right)^{2}\right]=\mathrm{E}\left[\left(Z_{t}-Z_{t-A_{t}}\right)^{2}\right]=\mathrm{E}\left[A_{t}\right]=\mathrm{E}[A]
$$

したがって，情報源の状態がウィーナー過程に従う場合，自乗 誤差の期待值は平均 AoI に等しい.

\section{2 情報源が連続時間マルコフ連鎖に従う場合 ${ }^{(8)}$}

$\left\{Z_{t}\right\}_{t \geq 0}$ が有限状態空間 $\mathcal{S}=\{1,2, \ldots,|\mathcal{S}|\}$ 上の既約な連続 時間マルコフ連鎖に従う場合を考える. $Q$ を $\left\{Z_{t}\right\}_{t \geqq 0}$ の遷移 速度行列とし, その $(i, j)$ 要素 $(i, j \in \mathcal{S})$ を $q_{i, j}:=[\boldsymbol{Q}]_{i, j}$ とす る. マルコフ連鎖の定義から, $\left\{Z_{t}\right\}_{t \geqq 0}$ は状態 $i(i \in \mathcal{S})$ にパ ラメータ $q_{i}:=-q_{i, i}>0$ の指数分布に従う時間滞在し, 確率 $q_{i, j} / q_{i}(j \in \mathcal{S}, j \neq i)$ で状態 $j$ に遷移する. 特に, 時間間隔 $\tau$ $(\tau \geqq 0)$ における $\left\{Z_{t}\right\}_{t \geqq 0}$ の推移確率は次式で与えられる.

$$
\operatorname{Pr}\left(Z_{t+\tau}=j \mid Z_{t}=i\right)=[\exp (\boldsymbol{Q} \tau)]_{i, j}, \quad i, j \in \mathcal{S}
$$

$\left\{Z_{t}\right\}_{t \geq 0}$ は既約かつ状態数が有限という仮定から, 定常 分布 $\pi_{i}(i \in \mathcal{S})$ が一意に定まり，任意の $i \in \mathcal{S}$ に対し $\lim _{t \rightarrow \infty} \operatorname{Pr}\left(Z_{t}=i\right)=\pi_{i}$ が成立する.

モニタの表示 $\left\{\hat{Z}_{t}\right\}_{t \geqq 0}$ と実際の状態 $\left\{Z_{t}\right\}_{t \geqq 0}$ との関係を特 徵付ける最も基本的な量は条件付確率 $\operatorname{Pr}\left(\hat{Z}_{t}=j \mid Z_{t}=i\right)$ $(i, j \in \mathcal{S})$ である. 情報源の状態 $\left\{Z_{t}\right\}_{t \geqq 0}$ と AoI 過程 $\left\{A_{t}\right\}_{t \geqq 0}$ が独立という仮定から,この条件付確率は AoI の定常分布 $A(x):=\operatorname{Pr}(A \leqq x)$ を用いて次式で与えられる(8). 


$$
\begin{aligned}
& \operatorname{Pr}\left(\hat{Z}_{t}=j \mid Z_{t}=i\right) \\
& \quad=\left[\int_{0}^{\infty} \exp \left[\left(\boldsymbol{\Pi}^{-1} \boldsymbol{Q}^{\top} \boldsymbol{\Pi}\right) x\right] \mathrm{d} A(x)\right]_{i, j}, \quad i, j \in \mathcal{S}
\end{aligned}
$$

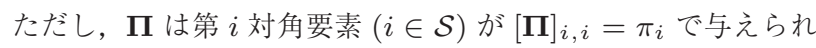
る対角行列を表す．更に，モニ夕の表示が実際の情報源の状態 と異なっている確率は以下のように上から押さえられる( ${ }^{(8)}$.

$$
\operatorname{Pr}\left(\hat{Z}_{t} \neq i \mid Z_{t}=i\right) \leqq q_{i} \mathrm{E}[A], \quad i \in \mathcal{S}
$$

したがって，ある $\epsilon>0$ に対し $\operatorname{Pr}\left(\hat{Z}_{t} \neq i \mid Z_{t}=i\right) \leqq \epsilon$ を達成 するためには, 平均 $\mathrm{AoI}$ が $\mathrm{E}[A] \leqq \epsilon / q_{i}$ となるようにモニタリ ングシステムを設計すればよいことが分かる.

\section{Aol の一般公式 (標本路解析)}

本章では式 (1) で定義される AoI 過程 $\left\{A_{t}\right\}_{t \geqq 0}$ を考察し, 幅 広い状況下で成り立つ一般公式を導出する４.1 では，決定論的 AoI 過程 $\left\{A_{t}\right\}_{t \geqq 0}$ を考え, その漸近頻度分布 $(3)$ が満たす公式 を導出する，次に 4.2 に拈いて，システムをエルゴード的確率 モデルとして表現し，4.1 の結果を用いて AoI の定常分布が満 たす公式を得る．以下では， $\mathbb{Z}^{+}=\{0,1, \ldots\}, \mathbb{N}=\{1,2, \ldots\}$ とし, AoI 過程 $\left\{A_{t}\right\}_{t \geqq 0}$ は右連続(注1) であると仮定する.

$\beta_{n}(n \in \mathbb{N})$ を $n$ 番目の情報更新時刻とし，便宜上 $\beta_{0}:=0$ と置く. 更に, $\beta_{n}<\beta_{n+1}\left(n \in \mathbb{Z}^{+}\right)$と仮定し, $X_{n}:=A_{\beta_{n}}$ $\left(n \in \mathbb{Z}^{+}\right)$を時刻 $\beta_{n}$ における AoI の值とする (図 2). このと き $A_{t}$ は，ある $n \in \mathbb{Z}^{+}$に対して次式で与えられる.

$$
A_{t}=X_{n}+\left(t-\beta_{n}\right), \quad t \in\left[\beta_{n}, \beta_{n+1}\right)
$$

すなわち, AoI 過程 $\left\{A_{t}\right\}_{t \geq 0}$ は $\beta_{n}$ と $X_{n}$ の組の列 $\left\{\left(\beta_{n}, X_{n}\right)\right\}_{n \in \mathbb{Z}^{+}}$により一意に定まる. $A_{\text {peak }, n}(n \in \mathbb{N})$ を $n$ 番目のピーク AoI（ $n$ 番目の情報更新直前の $\mathrm{AoI}$ の值）と する。

$$
A_{\text {peak }, n}=\lim _{t \rightarrow \beta_{n}-} A_{t}=X_{n-1}+B_{n}
$$

ただし $B_{n}(n \in \mathbb{N})$ は $n$ 番目の情報更新間隔を表す.

$$
B_{n}=\beta_{n}-\beta_{n-1}
$$

図 2 に示した AoI 過程 $\left\{A_{t}\right\}_{t \geqq 0}$ の例では, $\beta_{n}$ と $X_{n}$ に加え て, $n$ 番目の情報更新を行うパケットが保持しているタイムス タンプ $\alpha_{n}$ も表示している.

\subsection{Aol の頻度分布}

図 2 に示したような $\left\{\left(\beta_{n}, X_{n}\right)\right\}_{n \in \mathbb{Z}^{+}}$の標本路に対して, $\left\{A_{t}\right\}_{t \geqq 0}$ の漸近頻度分布を式 (3) で定義し, $\left\{A_{\text {peak }, n}\right\}_{n \in \mathbb{N}}$ と $\left\{X_{n}\right\}_{n \in \mathbb{Z}^{+}}$の漸近頻度分布を次式で定義する.

$$
A_{\text {peak }}^{\sharp}(x)=\lim _{N \rightarrow \infty} \frac{1}{N} \sum_{n=1}^{N} \mathbb{1}\left\{A_{\text {peak }, n} \leqq x\right\}, \quad x \geqq 0
$$

(注1) $: \lim _{t \rightarrow t_{0}+} A_{t}=A_{t_{0}}$.

$$
X^{\sharp}(x)=\lim _{N \rightarrow \infty} \frac{1}{N} \sum_{n=0}^{N-1} \mathbb{1}\left\{X_{n} \leqq x\right\}, \quad x \geqq 0
$$

$M_{t}(t \geqq 0)$ を時刻 $t$ までに行われた情報更新回数とする.

$$
M_{t}=\sup \left\{n \in \mathbb{Z}^{+} ; \beta_{n} \leqq t\right\}
$$

補題 1. $\lambda^{\dagger} \in(0, \infty)$ に対して次式が成立する ${ }^{(5)}$.

$$
\lim _{T \rightarrow \infty} \frac{M_{T}}{T}=\lambda^{\dagger} \Leftrightarrow \lim _{N \rightarrow \infty} \frac{\beta_{N}}{N}=\frac{1}{\lambda^{\dagger}}
$$

仮定 1 .

(i) ある $\lambda^{\dagger} \in(0, \infty)$ に対して $\lim _{N \rightarrow \infty}\left(\beta_{N} / N\right)=1 / \lambda^{\dagger}$ が成立する.

(ii) 式 (6) 並びに式 (7) における極限が全ての $x \geqq 0$ に対し て存在する.

補題 1 から, 仮定 1 (i) は平均情報更新間隔 $\bar{B}$ が情報更新率 $\lambda^{\dagger} \in(0, \infty)$ の逆数で与えられることを示している.

$$
\bar{B}=\lim _{N \rightarrow \infty} \frac{1}{N} \sum_{n=1}^{N} B_{n}=\lim _{N \rightarrow \infty} \frac{\beta_{N}}{N}=\frac{1}{\lambda^{\dagger}}
$$

定理 1 . 仮定 1 が成立するならば，全ての $x \geqq 0$ に対して式 (3) の極限が存在し, 次式が成立する ${ }^{(9)}$.

$$
A^{\sharp}(x)=\lambda^{\dagger} \int_{0}^{x}\left(X^{\sharp}(y)-A_{\text {peak }}^{\sharp}(y)\right) \mathrm{d} y, \quad x \geqq 0
$$

\section{2 モニタリングシステムの確率モデル}

この節では，モニタリングシステムを確率モデルとして表現 し, AoI 過程を定常かつエルゴード的な確率過程として定式化 する。このとき, 定理 1 は標本路ごとに成立するため, エルゴー ド性から AoI の定常分布に関する公式が得られる，記法を簡略 化するため, 以下では任意の確率変数 $Y$ に対して, 確率分布関 数を $Y(x)(x \geqq 0)$, ラプラス・スティルチェス変換 $(\mathrm{LST})$ を $y^{*}(s)(s>0)$ と表す.

$$
Y(x)=\operatorname{Pr}(Y \leqq x), \quad y^{*}(s)=\mathrm{E}[\exp (-s Y)]
$$

更に, $y^{(n)}(s)(s>0, n \in \mathbb{N})$ を $y^{*}(s)$ の $n$ 階導関数とする.

$$
y^{(n)}(s)=\frac{\mathrm{d}^{n}}{\mathrm{~d} s^{n}} y^{*}(s)=(-1)^{n} \mathrm{E}\left[Y^{n} \exp (-s Y)\right]
$$

一般に，モニタリングシステムでは，情報がモニタに配信さ れるまでに通信路やプロセッサなど複数のシステム構成要素を 経由する (図 1). 以降では, これら個別の構成要素を一体に捉 え，一つの「サービス機構」として考える (図 3). すなわち，情 報源のサンプリング直後, 情報を格納したパケットが生成され て即座にサービス機構に「到着」し，そのパケットの「離脱」時 点においてモニタの表示が更新されるとみなす。

一般に, サービス機構の内部では, 複数経路の存在する通信 ネットワークや処理順序制御を行うプロセッサ等の要因により, パケットの追い抜き(注2) が発生する可能性がある。追い抜かれた

(注 2）：後から到着したパケットが先に離脱すること. 


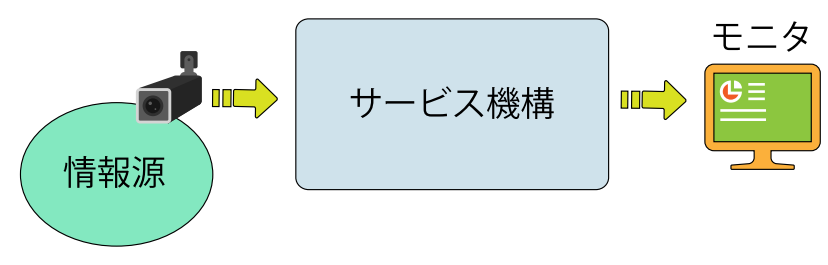

図 3 モニタリングシステムの模式図通信路やプ ロセッサを一体に, サービス機構として表現.

パケットは, 離脱時点においてモニタの表示よりも古い情報を 有するため, モニ夕の表示を更新しない。このように, サービ ス機構に到着するパケットは，それらが離脱するとき，情報更 新を行うもの（以下，情報更新パケットと呼ぶ）と行わないも のがある、情報更新を行わないパケットは直接的には AoI 影 響を与えないため, 図 2 では情報更新パケットの到着並びに離 脱時点のみを示している.

いかなるモニタリングシステムであっても，AoIに興味がある ならば，情報更新パケットのみに注目して考察すればよい。よっ て，本節では，情報更新パケットの到着時刻並びに離脱時刻の 列に注目したモデルを考える，図 2 から明らかなように，情報 更新パケットの離脱順序は，それらが保持するタイプスタンプ の昇順となる。したがって，パケットが保持する夕イムスタン プは, それらがサービス機構へ到着する時刻に等しいことに注 意すると，情報更新パケットが離脱する順序は，必ず到着した 順序と同一 (FIFO: First-in, First-out) になることが分かる.

各標本路上に扔いて, $n$ 番目 $(n \in \mathbb{N})$ の情報更新パケットの 到着時刻 (タイムスタンプ) を $\alpha_{n}, n$ 番目 $(n \in \mathbb{N})$ の情報更新 パケットの離脱時刻, すなわち $n$ 番目の情報更新時刻を $\beta_{n}$ と する。便宜上， $\alpha_{0}:=-A_{0}$ 及び $\beta_{0}=0$ と置き，時刻 0 に仮想 的な情報更新パケットの処理完了が発生したものとみなす。ま た， $n \in \mathbb{Z}^{+}$に対し $\alpha_{n} \leqq \alpha_{n+1}$ かつ $\alpha_{n} \leqq \beta_{n}<\beta_{n+1}$ であ るとする。 $(n-1)$ 番目と $n$ 番目 $(n \in \mathbb{N})$ の情報更新パケット の到着間隔を $G_{n}^{\dagger}=\alpha_{n}-\alpha_{n-1}, n$ 番目 $\left(n \in \mathbb{Z}^{+}\right)$の情報更新 パケットのシステム遅延を $D_{n}=\beta_{n}-\alpha_{n}$ とすると,

$$
\begin{aligned}
X_{n} & =D_{n}, \quad n \in \mathbb{Z}^{+} \\
A_{\text {peak }, n} & =\beta_{n}-\alpha_{n-1} \\
& =G_{n}^{\dagger}+D_{n}=D_{n-1}+B_{n}, \quad n \in \mathbb{N}
\end{aligned}
$$

が得られる。ただし， $B_{n}$ は式 (5) で定義されている.

仮定 2.（i）情報更新パケットの平均到着率(注3) は正かつ有限 である。すなわち次式が確率 1 で成立する.

$$
\lim _{T \rightarrow \infty} \frac{1}{T} \sum_{n=1}^{\infty} \mathbb{1}\left\{\alpha_{n} \leqq T\right\}=\lambda^{\dagger} \in(0, \infty)
$$

（ii）システムは率安定である。すなわち，情報更新パケット の平均処理完了率（情報更新率）は情報更新パケットの平均到 着率に等しい.より正確には

$$
\lim _{T \rightarrow \infty} \frac{M_{T}}{T}=\lambda^{\dagger}
$$

(注3)：単位時間当りの平均到着数.
が確率 1 で成立する.ただし $M_{t}$ は式 (8) で定義されている. (iii) 確率過程 $\left\{\left(\beta_{n}, D_{n}\right)\right\}_{n \in \mathbb{N}}$ は定常かつエルゴード的である. 情報更新パケットの平均到着間隔を $\mathrm{E}\left[G^{\dagger}\right]$ で表す.

$$
\mathrm{E}\left[G^{\dagger}\right]=\lim _{N \rightarrow \infty} \frac{1}{N} \sum_{n=1}^{N} G_{n}^{\dagger}=\lim _{N \rightarrow \infty} \frac{\alpha_{N}}{N}
$$

このとき, 補題 1 から, 仮定 2 (i), (ii) の下では

$$
\mathrm{E}\left[G^{\dagger}\right]=\frac{1}{\lambda^{\dagger}}
$$

が成立する。 また, 仮定 2 (iii) の下では, 式 (6) の $A_{\text {peak }}^{\sharp}(x)$ 並びに式 $(7)$ の $X^{\sharp}(x)$ が確率 1 で存在する. 更に, 定理 1 か ら, $A^{\sharp}(x)$ も存在し, 以下が確率 1 で成立する。

$$
A^{\sharp}(x)=A(x), \quad A_{\text {peak }}^{\sharp}(x)=A_{\text {peak }}(x), \quad X^{\sharp}(x)=D(x)
$$

ただし， $A, A_{\text {peak }}, D$ はそれぞれ, 定常状態におけるAoI, ピーク AoI, システム遅延を表す確率変数である. なお, 定義 より $A \stackrel{\mathrm{d}}{=} A_{t}, D \stackrel{\mathrm{d}}{=} D_{n}, A_{\text {peak }} \stackrel{\mathrm{d}}{=} A_{\text {peak }, n}$ が成立する.ただ し $\stackrel{\mathrm{d}}{=}$ 分布が等しいことを表す. 定理 1 から以下を得る.

定理 2. 仮定 2 を満たす FIFO 確率モデルでは以下が成立す る(9).

(i) AoI の確率密度関数 $a(x)(x \geqq 0)$ は次式で与えられる.

$$
a(x)=\lambda^{\dagger}\left(D(x)-A_{\text {peak }}(x)\right)
$$

(ii) $\operatorname{AoI} の \operatorname{LST} a^{*}(s)(s>0)$ は次式で与えられる.

$$
a^{*}(s)=\lambda^{\dagger} \cdot \frac{d^{*}(s)-a_{\text {peak }}^{*}(s)}{s}
$$

(iii) AoI の $k$ 次積率 $(k \in \mathbb{N})$ は, $\mathrm{E}\left[\left(A_{\text {peak }}\right)^{k+1}\right]<\infty$ かつ $\mathrm{E}\left[D^{k+1}\right]<\infty$ ならば，次式で与えられる。

$$
\mathrm{E}\left[A^{k}\right]=\lambda^{\dagger} \cdot \frac{\mathrm{E}\left[\left(A_{\text {peak }}\right)^{k+1}\right]-\mathrm{E}\left[D^{k+1}\right]}{k+1}
$$

\section{3 平 均 Aol}

平均 AoI は, 式 (12) において $k=1$ とすることにより得ら れる.

$$
\mathrm{E}[A]=\lambda^{\dagger} \cdot \frac{\mathrm{E}\left[\left(A_{\text {peak }}\right)^{2}\right]-\mathrm{E}\left[D^{2}\right]}{2}
$$

ここで，式 (5), 式 (9), 式 (10) 並びに式 (11) から

$$
\lambda^{\dagger}=\frac{1}{\mathrm{E}\left[G^{\dagger}\right]}=\frac{1}{\mathrm{E}\left[A_{\text {peak }}\right]-\mathrm{E}[D]}=\frac{1}{\mathrm{E}[B]}
$$

を得る。ただし $B \stackrel{\mathrm{d}}{=} B_{n}=A_{\text {peak }, n}-D_{n-1}$ （式 (4)）は情報 更新間隔を表す確率変数である. 式 (14) に注意して式 (13)を 書き換えると

$$
\begin{aligned}
\mathrm{E}[A] & =\frac{\mathrm{E}\left[A_{\text {peak }}^{2} / 2-D^{2} / 2\right]}{\mathrm{E}\left[G^{\dagger}\right]} \\
& =\frac{\mathrm{E}\left[\left(A_{\text {peak }}+D\right)\left(A_{\text {peak }}-D\right) / 2\right]}{\mathrm{E}[B]}
\end{aligned}
$$




$$
=\frac{\mathrm{E}\left[\left(A_{\mathrm{peak}}+D\right) B / 2\right]}{\mathrm{E}[B]}
$$

を得る。式 (15) の分子は図 2 における台形 $\alpha_{n-1}$ - $A_{\text {peak, } n^{-}}$ $X_{n}-\alpha_{n}$ の面積に相当しており，これを平均到着間隔 $\mathrm{E}\left[G^{\dagger}\right]$ で 割ることで平均 AoI $\mathrm{E}[A]$ が与えられる. なお， $\mathrm{E}\left[\left(A_{\text {peak }}\right)^{2}\right]=$ $\mathrm{E}\left[\left(G_{n}^{\dagger}+D_{n}\right)^{2}\right]=\mathrm{E}\left[\left(G^{\dagger}\right)^{2}\right]+2 \mathrm{E}\left[G_{n}^{\dagger} D_{n}\right]+\mathrm{E}\left[D^{2}\right]$ に注意する と, 式 (15) は

$$
\mathrm{E}[A]=\frac{\mathrm{E}\left[G_{n}^{\dagger} D_{n}\right]+\mathrm{E}\left[\left(G^{\dagger}\right)^{2}\right] / 2}{\mathrm{E}\left[G^{\dagger}\right]}
$$

と書き換えることができる，多くの文献では式 (17) を平均 AoI の基本公式として扱っている。一方，式 (16)の分子は，図 2 に おける台形 $\beta_{n}-X_{n}-A_{\text {peak }, n+1}-\beta_{n+1}$ の面積の平均に対応して おり，これを $\mathrm{E}[B]$ で割ることでも平均 AoI $\mathrm{E}[A]$ を得ることが できる.

\section{5. 一般公式の適用例}

本章では, 定理 2 の適用例として, サービス機構が単一サー バの待ち行列モデルで表される場合を考察する。これは例えば， 図 1 のモニタリングシステムにおいて，プロセッサの処理時間 がボトルネックとなり通信遅延は無視できるほど小さい場合や， あるいは，送信側端末が接続するアクセスネットワークがボト ルネックとなりプロセッサの処理時間やプロセッサからモニタ への通信遅延は無視できるほど小さい場合等に相当する.

以下では，サーバに拈けるサービス時間の系列 $\left\{H_{n}\right\}_{n \in \mathbb{Z}^{+}}$は 独立かつ同一に分布する (i.i.d.: independent and identically distributed) と仮定し，H をサービス時間分布に従う確率変数 とする。また，単一のアプリケーションのみがサーバを利用す ると想定し，他のアプリケーションに由来するパケットの存在 はここでは考えないものとする。

\section{1 モニタからのフィードバックがある場合}

モニタから送信側端末へのフィードバックがある場合, 最後 に送出したパケットに対するサービス完了通知を受け取るまで は新たなサンプリングを行わない方式を取ることで，サービス 機構に打ける待ち行列遅延をなくすことができる。これにより， 各パケットの遅延時間はそのサービス時間に等しくなる.

$D_{n}=H_{n}, \quad n \in \mathbb{Z}^{+}$

このとき, $n-1$ 番目と $n$ 番目のサンプリング間隔 $G_{n}$ は $n-1$ 番目のサービス時間 $H_{n-1}$ 以上の值を取り, 更に, 全てのパ ケットは情報更新パケットとなる.

$$
G_{n}^{\dagger}=G_{n}, \quad n \in \mathbb{N}
$$

本節では，モニ夕の更新直後に送信側へサービス完了が通知 されると仮定し, サンプリング間隔 $G_{n}(n \in \mathbb{N})$ がある非負関 数 $f(x)(x \geqq 0)$ を用いて次式で与えられる場合を考える.

$$
G_{n}=H_{n-1}+f\left(H_{n-1}\right)
$$

すなわち, $n-1$ 番目の情報更新が起こった直後における AoI の值 $D_{n-1}=H_{n-1}$ に応じて, $n$ 番目のサンプリング時点が 決定される．例えば消費電力の観点からサンプリング頻度に制 約のある場合, 待機時間を決める関数 $f(x)$ はその制約を満足す るように設定される。また，6.1 で示すように，サンプリング 頻度に制約のない場合であっても, 平均 AoI 最小化の観点では 即時サンプリング $f(x)=0(x \geqq 0)$ は必ずしも最適でない.

$\left\{H_{n}\right\}_{n \in \mathbb{Z}^{+}}$が i.i.d. であるという仮定並びに式 (20) から， $\left\{G_{n}\right\}_{n \in \mathbb{N}}$ は i.i.d. である. また, $H_{n-1}$ と $H_{n}$ の独立性並び に式 (18) と式 (19) から $D_{n}$ と $G_{n}^{\dagger}(n \in \mathbb{N})$ は独立であること が分かる. したがって, 式 (10), 式 (18), 並びに式 (19) から, ピークAoI の LST は次式で与えられる.

$$
a_{\text {peak }}^{*}(s)=h^{*}(s) \mathrm{E}\left[e^{-s(H+f(H))}\right]
$$

更に，システムが定常であるとき定理 2 が適用可能であり，次 の結果を得る。

定理 3. 式 (20) で定められるサンプリング間隔を用いる定常な システムに扔いて, AoI の LST 並びに $n$ 次積率 $(n=1,2, \ldots)$ は次式で与えられる。

$$
\begin{aligned}
a^{*}(s) & =h^{*}(s) \cdot \frac{1-\mathrm{E}\left[e^{-s(H+f(H))}\right]}{s(\mathrm{E}[H]+\mathrm{E}[f(H)])} \\
\mathrm{E}\left[A^{n}\right] & =\sum_{m=0}^{n} \frac{\mathrm{E}\left[H^{n-m}\right]}{(n-m) !} \cdot \frac{n ! \mathrm{E}\left[(H+f(H))^{m+1}\right]}{(m+1) !(\mathrm{E}[H]+\mathrm{E}[f(H)])}
\end{aligned}
$$

\section{2 モニタからのフィードバックがない場合}

モニタからのフィードバックがない場合，送信側端末で自律 的にサンプリング間隔を決定することになる。このような状況 を考察する際には, 定常かつエルゴード的な待ち行列システム が標準的に用いられる。この節では, サンプリング間隔 (パケッ トの到着間隔) $\left\{G_{n}\right\}_{n \in \mathbb{N}}$ は i.i.d. と仮定する. パケットの平均 到着率を $\lambda:=1 / \mathrm{E}[G]$, トラヒック強度を $\rho:=\lambda \mathrm{E}[H]$ とする. $\tilde{G}$ 並びに $\tilde{H}$ を残余到着間隔(注4)並びに残余サービス時間(注5)を 表す確率変数とする。なお，これらの LST は次式で与えられる.

$$
\tilde{h}^{*}(s)=\frac{1-h^{*}(s)}{s \mathrm{E}[H]}, \quad \tilde{g}^{*}(s)=\frac{1-g^{*}(s)}{s \mathrm{E}[G]}, \quad s>0
$$

以下では $\rho<1$ であり，システムは安定であると仮定する.

\subsection{1 先着順サービス $\mathrm{Gl} / \mathrm{Gl} / 1$}

最初に，パケットの到着間隔並びにサービス時間がそれぞれ i.i.d. である FIFO GI/GI/1 を考える。パケットが FIFO で サービスされる場合, 全てのパケットの処理後に情報更新が行 われるため $G_{n}^{\dagger}=G_{n}(n \in \mathbb{N})$ が成立する. したがって，

$$
G^{\dagger} \stackrel{\mathrm{d}}{=} G, \quad \lambda^{\dagger}=\lambda=\frac{1}{\mathrm{E}[G]}
$$

（注4）: 定常状態において次の到着が発生するまでの残り時間. (注 5)：定常状態に扔いてサーバが稼動中 (サービス中) であるという条件の下で, 進 行中のサービスが終了するまでの残り時間. 
である。また, FIFO の場合, $A_{\text {peak }, n}$ は次式を満たす。

$$
\begin{aligned}
A_{\text {peak }, n} & = \begin{cases}G_{n}^{\dagger}+H_{n}^{\dagger}, & G_{n}^{\dagger}>D_{n-1} \\
D_{n-1}+H_{n}^{\dagger}, & G_{n}^{\dagger} \leqq D_{n-1}\end{cases} \\
& =\max \left(D_{n-1}, G_{n}^{\dagger}\right)+H_{n}^{\dagger}
\end{aligned}
$$

ただし $H_{n}^{\dagger}$ は $n$ 番目の情報更新パケットのサービス時間を表す. $G_{n}^{\dagger}$ と $D_{n-1}$ は独立であることに注意して, 式 (22), 式 (23) 並びに定理 2 を用いると以下の結果を得る(9).

補題 2. $\rho<1$ のとき, FIFO GI/GI/1 では以下が成立する.

$$
a^{*}(s)=\frac{d^{*}(s)-a_{\text {peak }}^{*}(s)}{s \mathrm{E}[G]}
$$

ただし

$$
\begin{array}{r}
a_{\text {peak }}^{*}(s)=\left[\int_{0}^{\infty} e^{-s x} G(x) \mathrm{d} D(x)+\int_{0}^{\infty} e^{-s x} D(x) \mathrm{d} G(x)\right. \\
\left.-\mathrm{E}\left[\mathbb{1}\{G=D\} e^{-s G}\right]\right] h^{*}(s)
\end{array}
$$

\section{2.2 先着順サービス $M / G I / 1, G I / M / 1$}

本項では FIFO GI/GI/1 において, 到着間隔が平均 $\mathrm{E}[G]=$ $1 / \lambda$ の指数分布に従う場合に相当する FIFO M/GI/1 とサー ビス時間が平均 $\mathrm{E}[H]=1 / \mu$ の指数分布に従う場合に相当する FIFO GI/M/1 を考える.これらは待ち行列理論における基本 モデルであり，遅延分布に関して以下の結果が知られている.

(i) $\rho<1$ のとき, FIFO M/GI/1 では以下が成立する.

$$
d^{*}(s)=\frac{(1-\rho) s}{s-\lambda+\lambda h^{*}(s)} \cdot h^{*}(s)
$$

(ii) $\rho<1$ のとき, FIFO GI/M/1 では以下が成立する.

$$
\begin{aligned}
\operatorname{Pr}(D \leqq x) & =1-e^{-(\mu-\mu \gamma) x} \quad(x \geqq 0) \\
d^{*}(s) & =\frac{\mu-\mu \gamma}{s+\mu-\mu \gamma}
\end{aligned}
$$

ただし $\gamma$ は以下の方程式の唯一解である.

$$
x=g^{*}(\mu-\mu x), \quad 0<x<1
$$

補題 2 に対して, これらを用いると以下の結果を得る(9).

定理 4. (i) FIFO M/GI/1 では以下が成立する.

$$
\begin{aligned}
a^{*}(s)= & \rho d^{*}(s) \tilde{h}^{*}(s)+d^{*}(s+\lambda) \cdot \frac{\lambda}{s+\lambda} \cdot h^{*}(s) \\
= & d^{*}(s)-\frac{(1-\rho) s}{s+\lambda h^{*}(s+\lambda)} \cdot h^{*}(s) \\
\mathrm{E}[A]= & \frac{\lambda \mathrm{E}\left[H^{2}\right]}{2(1-\rho)}+\mathrm{E}[H]+\frac{1-\rho}{\rho h^{*}(\lambda)} \cdot \mathrm{E}[H] \\
\mathrm{E}\left[A^{2}\right]= & \frac{2(1-\rho)\left[1+\rho h^{*}(\lambda)-\lambda\left(-h^{(1)}(\lambda)\right)\right](\mathrm{E}[H])^{2}}{\left(\rho h^{*}(\lambda)\right)^{2}} \\
& \quad+\frac{\lambda \mathrm{E}\left[H^{3}\right]}{3(1-\rho)}+\frac{\left(\lambda \mathrm{E}\left[H^{2}\right]\right)^{2}}{2(1-\rho)^{2}}+\frac{\mathrm{E}\left[H^{2}\right]}{1-\rho}
\end{aligned}
$$

(ii) FIFO GI/M/1 では以下が成立する.

$$
\begin{aligned}
a^{*}(s)= & {\left[\rho d^{*}(s)+\tilde{g}^{*}(s)-\tilde{g}^{*}(s+\mu-\mu \gamma)\right] \frac{\mu}{s+\mu} } \\
\mathrm{E}[A]= & \frac{\mathrm{E}\left[G^{2}\right]}{2 \mathrm{E}[G]}+\mathrm{E}[H]+\frac{\rho}{1-\gamma}\left(-g^{(1)}(\mu-\mu \gamma)\right) \quad(24) \\
\mathrm{E}\left[A^{2}\right]= & \frac{\mathrm{E}\left[G^{3}\right]}{3 \mathrm{E}[G]}+\rho \mathrm{E}\left[G^{2}\right]+2(\mathrm{E}[H])^{2} \\
& +\frac{\rho}{1-\gamma}\left[g^{(2)}(\mu-\mu \gamma)+2\left(1+\frac{1}{1-\gamma}\right)\right. \\
& \left.\times\left(-g^{(1)}(\mu-\mu \gamma)\right) \mathrm{E}[H]\right]
\end{aligned}
$$

\subsection{3 割込み後着順サービス $\mathrm{Gl} / \mathrm{Gl} / 1$}

次に割込み後着順サービス $\mathrm{GI} / \mathrm{GI} / 1$ を考える。このシステム では，パケットをサービス中に新たなパケットが到着した場合， その時点で行っているサービスを中断し, 新しく到着したパケッ トのサービスを開始する。もし，パケットのサービス中に新た なパケットが到着しなければ, サービス完了後に情報更新が行 われる.よって, 情報更新パケットのみに注目すれば, FIFOで サービスされていくことになり, 定理 2 が成立する。 また，パ ケットの到着間隔 $\left\{G_{n}\right\}_{n \in \mathbb{N}}$ 並びにサービス時間 $\left\{H_{n}\right\}_{n \in \mathbb{Z}^{+}}$ がi.i.d. である場合, 情報更新パケットの到着間隔 $\left\{G_{n}^{\dagger}\right\}_{n \in \mathbb{N}}$ 並 びにサービス時間 $\left\{H_{n}^{\dagger}\right\}_{n \in \mathbb{Z}^{+}}$も i.i.d. となるため, 情報更新パ ケットのみに注目すると補題 2 も成立する. なお, 仮定 2 は情 報更新パケットのみに課されているため, 以下の結果は $\rho \geqq 1$ の場合も適用可能である.

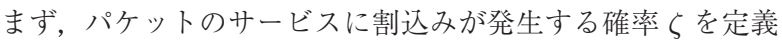
する.

$$
\zeta=\operatorname{Pr}(G<H)
$$

もし $\zeta=1$ ならば, 全てのサービスが確率 1 で割り达まれるた め, 情報更新は行われず, AoI は時間とともに単調に増加する. 一方, $\zeta=0$ ならば, 到着する全てのパケットのサービスが完 了するため, $d^{*}(s)=h^{*}(s)$ かつ $a_{\text {peak }}^{*}(s)=g^{*}(s) h^{*}(s)$ であ る.よって, 以下では次の仮定を置く.

仮定 3. $\operatorname{Pr}(H=G)=0$ かつ $0<\zeta<1$.

割込み後着順サービスでは, 到着したパケットのサービス中 に新たな到着がなければ情報更新が行われるため, 情報更新パ ケットのシステム遅延は

$$
D_{n}=H_{n}^{\dagger} \stackrel{\mathrm{d}}{=} H_{<G}
$$

で与えられる。ただし $H_{<G}$ は到着間隔より短いという条件下 でのサービス時間を表す確率変数である.

次にピーク AoI を考える. $n$ 番目の情報更新パケットのサー ビス終了後, $m$ 番目 $(m \in \mathbb{N})$ に到着したパケットが $(n+1)$ 番 目の情報更新パケットとなる確率は $\zeta^{m-1}(1-\zeta)$ であり, この 場合のピークAoI は次式で与えられる.

$$
A_{\text {peak }, n+1} \stackrel{\mathrm{d}}{=} G_{>H}+\sum_{i=1}^{m-1} G_{<H}^{[i]}+H_{<G}
$$


ただし $G_{>H}$ はサービス時間より長いという条件下でのパケッ トの到着間隔, $G_{<H}^{[i]}(i \in \mathbb{N})$ はサービス時間より短いという条 件下でのパケットの到着間隔を表す。定義から, $H_{<G,}, G_{<H}$, $G_{>H}$ の LST は次式で与えられる.

$$
\begin{aligned}
& h_{<G}^{*}(s)=\frac{1}{1-\zeta} \int_{0}^{\infty} e^{-s x}(1-G(x)) \mathrm{d} H(x) \\
& g_{<H}^{*}(s)=\frac{1}{\zeta} \int_{0}^{\infty} e^{-s x}(1-H(x)) \mathrm{d} G(x) \\
& g_{>H}^{*}(s)=\frac{1}{1-\zeta} \int_{0}^{\infty} e^{-s x} H(x) \mathrm{d} G(x)
\end{aligned}
$$

定理 2 から以下の結果を得る(9).

定理 5. 割込み後着順サービス GI/GI/1 では以下が成立する.

$$
\begin{aligned}
a^{*}(s) & =h_{<G}^{*}(s) \cdot \tilde{g}^{*}(s) \cdot \frac{1-\zeta}{1-\zeta g_{<H}^{*}(s)} \\
\mathrm{E}[A] & =\mathrm{E}\left[H_{<G}\right]+\frac{E\left[G^{2}\right]}{2 \mathrm{E}[G]}+\frac{\zeta}{1-\zeta} \mathrm{E}\left[G_{<H}\right]
\end{aligned}
$$

\subsection{4 割込み後着順サービス $\mathrm{M} / \mathrm{Gl} / 1, \mathrm{Gl} / \mathrm{M} / 1$}

到着間隔あるいはサービス時間が指数分布に従う特別な場合 を考える。これらの場合, 式 (25) は単純な形を取り, AoI の積 率を簡単に計算することができる(9).

系 1.（i） 割达み後着順サービス $M / G I / 1$ では以下が成立 する。

$$
\begin{aligned}
a^{*}(s) & =\frac{\lambda h^{*}(s+\lambda)}{s+\lambda h^{*}(s+\lambda)} \\
\mathrm{E}[A] & =\frac{\mathrm{E}[H]}{\rho h^{*}(\lambda)} \\
\mathrm{E}\left[A^{2}\right] & =2\left[1-\lambda\left(-h^{(1)}(\lambda)\right)\right]\left(\frac{\mathrm{E}[H]}{\rho h^{*}(\lambda)}\right)^{2}
\end{aligned}
$$

(ii) 割込み後着順サービス GI/M/1 では以下が成立する.

$$
\begin{aligned}
a^{*}(s) & =\tilde{g}(s) \cdot \frac{\mu}{s+\mu} \\
\mathrm{E}\left[A^{n}\right] & =\sum_{m=0}^{n} \frac{n ! E\left[G^{m+1}\right](\mathrm{E}[H])^{n-m}}{(m+1) ! \mathrm{E}[G]}, n \in \mathbb{N}
\end{aligned}
$$

次に, 同じ到着率と同じ平均サービス時間を持つ, 二つの 割込み後着順サービス $\mathrm{M} / \mathrm{GI} / 1$ 並びに割込み後着順サービス $\mathrm{GI} / \mathrm{M} / 1$ における AoI の比較評価を考える. $G^{\langle k\rangle}, H^{\langle k\rangle}, A^{\langle k\rangle}$ $(k=1,2)$ をそれぞれ, $k$ 番目のシステムにおけるパケットの到 着間隔, サービス時間, AoI を表す確率変数とする.

系 2. (i) 同一の到着率と同一の平均サービス時間を持つ割 达み後着順サービス $M / G I / 1$ において以下が成立する。

$$
H^{\langle 1\rangle} \leqq_{\mathrm{cX}} H^{\langle 2\rangle} \Rightarrow \mathrm{E}\left[A^{\langle 2\rangle}\right] \leqq \mathrm{E}\left[A^{\langle 1\rangle}\right]
$$

ただし $\varliminf_{\mathrm{cx}}$ は凸順序を表す(注6).

(ii) 同一の到着率と同一の平均サービス時間を持つ割込み後 着順サービス GI/M/1 において以下が成立する.

(注6) $: X \leqq_{c x} Y \Leftrightarrow$ 全ての凸関数 $\phi$ に対して $\mathrm{E}[\phi(X)] \leqq \mathrm{E}[\phi(Y)]$.

$$
G^{\langle 1\rangle} \leqq_{\mathrm{cx}} G^{\langle 2\rangle} \Rightarrow A^{\langle 1\rangle} \leqq_{\mathrm{st}} A^{\langle 2\rangle}
$$

ただし， $A^{\langle 2\rangle} \Rightarrow \mathrm{E}\left[A^{\langle 1\rangle}\right] \leqq \mathrm{E}\left[A^{\langle 2\rangle}\right]$ が成立する.

\section{Aol の制御}

本章では，上記の理論的結果を基に，AoI 制御に関する基本 的考え方を紹介する. AoI の制御を行う主体は情報源をサンプ リングする送信側端末, 並びに情報をモニタへ配信するサービ ス機構である. 送信側端末はサンプリング間隔の系列を適切に 決定することにより, サービス機構はパケットをサービスする順 番 (処理順序) を適切にスケジューリングすることにより, AoI の值を制御することができる，以下では，6.1 において送信側 端末でのサンプリング間隔制御を，6.2 においてサービス機構 での処理順序制御を考察する。

\section{1 サンプリング間隔制御}

5. では，モニタからのフィードバックが得られる場合と得ら れない場合について理論的解析を行った。サンプリング間隔制 御の観点では，フィードバックの有無により実行可能な方策が 異なるため，本節ではこれらを個別に考察する.

\subsection{1 モニタからのフィードバックがある場合}

5.1 で考察した，モニタからのフィードバックがある状況で は, サンプリング間隔の制御は式 $(20)$ における待機時間関数 $f(x)$ を適切に設定することにほかならない. 式 (21) から, こ のような状況下に扔ける平均 AoI は

$$
\begin{aligned}
\mathrm{E}[A] & =\mathrm{E}[H]+\frac{\mathrm{E}\left[(H+f(H))^{2}\right]}{2(\mathrm{E}[H+f(H)])} \\
& =\mathrm{E}[H]+\frac{1+(\mathrm{Cv}[H+f(H)])^{2}}{2} \cdot(\mathrm{E}[H+f(H)])
\end{aligned}
$$

で与えられる。ただ, $\mathrm{Cv}[Y]$ は確率変数 $Y$ の変動係数を表す. 変動係数は確率変数のばらつきの大きさを表現する無次元量で あり, 標準偏差を平均で除した值として定義される.上式から, 待機時間関数 $f(x)$ は平均サンプリング間隔 $\mathrm{E}[H+f(H)]$ 並び にサンプリング間隔の変動係数を通じて平均 AoI $\mathrm{E}[A]$ に影響 を与える。(式 $(20)$ から $H+f(H)$ はサンプリング間隔を表す ことに注意.) 即時サンプリング方策 $f(x)=0(x \geqq 0)$ を用い た場合, 平均サンプリング間隔は最小となるが, ごく特殊な場 合を除き，サンプリング間隔の変動係数は最小とならない.

そこで, 平均值 $\mathrm{E}[H+f(H)]$ 並びに変動係数 $\mathrm{Cv}[H+f(H)]$ の兼ね合いを取ることのできる関数形として, 次式を仮定す る(10).

$$
\begin{aligned}
& f(x)=\max (c \mathrm{E}[H]-x, 0) \\
& \text { ただし }, c \geqq 0 \text { はパラメータである.このとき, } \\
& H+f(H)=\max (c \mathrm{E}[H], H)
\end{aligned}
$$

(注 7$): X \leqq_{\mathrm{st}} Y \Leftrightarrow$ 全ての $x$ に対して $\operatorname{Pr}(X>x) \leqq \operatorname{Pr}(Y>x)$. 


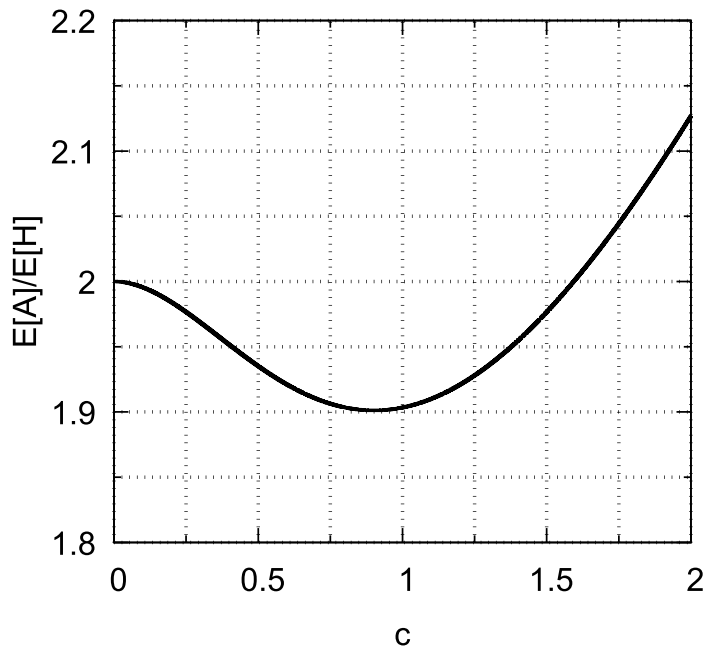

図 4 式 (26) のサンプリング方策下での正規化され た平均 Aol サービス時間が指数分布に従う 場合.

並びに

$$
G_{n}=\max \left(c \mathrm{E}[H], H_{n-1}\right)
$$

が成立し，これは遅延時間が $c \mathrm{E}[H]$ 未満であるときはサンプリ ング間隔が $c \mathrm{E}[H]$ に一致するまで待機し, 遅延時間が $c \mathrm{E}[H]$ 以 上であるときは即座にサンプリングを行う方策に相当する。ま た， $c=0$ ならば $f(x)=0(x \geqq 0)$ であるため, 即時サンプリ ング方策を特別な場合として含む.

文献 (10) では, 平均 AoI を最小化する関数 $f(x)(x \geqq 0)$ を 求める変分問題が考察されており，ある $c \geqq 0$ が存在して式 (26) がその最適解を与えることの証明, 並びに, 即時サンプリ ングが最適となる必要十分条件が与えられている。

ここでは, サービス時間が指数分布に従う場合の数值例を示 す.この場合, 式 (26) の方策を用いたときの平均 AoI は次式 で与えられることが単純な計算により確かめられる.

$$
\mathrm{E}[A]=\frac{(c+2)\left(c+2 e^{-c}\right)}{2\left(c+e^{-c}\right)} \cdot \mathrm{E}[H]
$$

図 4 に, 上式の $\mathrm{E}[A] / \mathrm{E}[H]$ を $c$ の関数としてプロットした結果 を示す. 図から，即時サンプリング方策 $(c=0)$ はこの場合に は最適でないことが分かる. 更に, 平均 $\mathrm{AoI} \mathrm{E}[A]$ を最小化す る点は $c^{2}=2 e^{-c}(c>0)$ の根 $c^{*} \approx 0.901$ で与えられる.

\subsection{2 モニタからのフィードバックがない場合}

5.2 で考察した, モニタからのフィードバックがない状況で は，確率分布 $G(x)(x \geqq 0)$ を通じてサンプリング間隔が決定 される。本項では, サービス時間が指数分布に従う先着順サー ビスモデル (FIFO GI/M/1) を考える。サンプリング間隔を生 成する分布として，正の変動係数を持つガンマ分布と変動係数

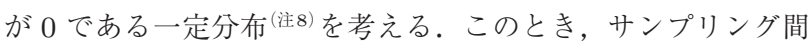
隔分布は, 平均 $\mathrm{E}[G]$ 及び变動係数 $\mathrm{Cv}[G]$ により一意に定まる ことに注意せよ。なお，一定分布は，ガンマ分布において平均

(注 8)：確率 1 で $G=\mathrm{E}[G]$ となる分布であり $\mathrm{Cv}[G]=0$ を満たす.

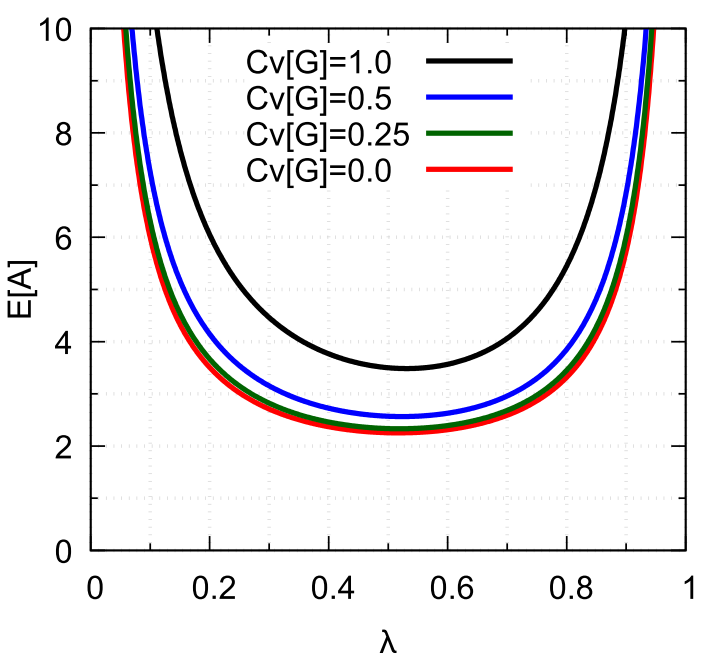

図 5 FIFO GI/M/1 における平均 Aol $(\mathrm{E}[H]=1)$

$\mathrm{E}[G]$ を一定に保ち変動係数を $\mathrm{Cv}[G] \rightarrow 0+$ としたときの極限 分布に一致する。

$\mathrm{E}[H]=1$ と正規化し, 式 (24) を用いて平均 AoI を計算した 結果を図 5 に示す. 図から, 平均 AoI E $[A]$ はサンプリング頻 度 $\lambda=1 / \mathrm{E}[G]$ に関して $\mathrm{U}$ 字形のグラフを描くことが分かる。 これは, サンプリング頻度 $\lambda$ を増加させると, 情報更新頻度と 遅延時間が同時に増加するためである。情報更新頻度の増加は 平均 AoI を減少させる要因である一方, 遅延時間の増加は平均 AoI の増加につながる. 加えて, $\lambda$ が小さい領域では $\lambda$ の増加 に関する遅延時間の増加はなだらかであり，入が大きい領域で は遅延時間の増加は顕著となるため, 図のような $\mathrm{U}$ 字形のグラ フが得られる結果となる。したがって, モニタからのフィード バックがない状況では, 更新頻度と遅延時間の兼ね合いを考慮 した適切なサンプリング間隔を設定しなければならない. 更に, サンプリング間隔のばらつきは可能な限り小さい方が好ましい という系 2 (ii) と同様の結果も図 5 から読み取れる。

\section{2 処理順序制御}

情報源から情報表示システムへ至る経路上において, 同じ情 報源の情報を保持するパケットが複数存在する場合がある．例 えば，受信したパケットを処理して表示するサーバがある場合， サーバへ到着したパケットは待ち行列を形成する。この際，こ れらのパケットをあらかじめ定められた処理順序制御則に従っ て処理することになる．本節では，AoI の值を含む情報処理機 構の状態とは独立に, あらかじめ与えられた点過程に従ってサ ンプリングが行われる, すなわち, あらかじめ与えられた確率 過程に従って情報パケットが到着するという仮定の下で, 処理 順序制御を考える.AoI を良好な状態に保つことを目的とした パケットの処理順序を決める際に利用可能な情報には, 以下の ようなものが考えられる。

(a) 過去の履歴によって明らかとなるもの

・過去に到着した各パケットの到着時刻とタイムスタンプ

・既に処理が完了したパケットのサービス時間 
・現時点で処理中のパケットの経過サービス時間

(b) 先験的あるいは統計的推定によって得られるもの

・パケットの到着間隔分布あるいは積率

・パケットのサービス時間分布あるいは積率

(c) 特別な場合において利用可能なもの

・将来，到着するパケットの到着時刻やタイムスタンプ

・現時点で処理中のパケットの残りサービス時間

処理順序制御は，上記の情報を基に処理を行うパケットを選 択することである。一般に，処理順序制御則は非割込み形 (NP: non-preemptive) と割込み形 (P: preemptive) の二つの形に分 類することができる。非割込み形とは，サーバが一旦，あるパ ケットの処理を開始すると，その処理が終了するまで，他のパ ケットの処理を開始しない制御則であり, 先着順サービスはそ の典型例である。なお，先着順サービスは，到着時刻に関する 過去の情報のみを用いた処理順序制御則の中で，パケットの待 ち時間の分散を最小化する。一方, 割込み形とは, サーバで処 理中のパケットに割込みをかけ，別のパケットの処理を開始す ることを許す制御則である。

非割込み形ではパケットの処理が終了した時点でスケジュー ラが起動される。 AoI の文脈では, 複数のパケットが処理待ち 状態にある場合, 最も新しい情報が格納されたパケットの処理 を開始する非割込み後着順サービスが合理的であると思われる。 一方，割込み形では，あるパケットの処理中に，より新しい情報 が格納されたパケットが到着したときに，スケジューラが起動 される，基本モデルでは，このような場合，必ず割込みを行う。

一般に, 平均 AoI を最小化する処理順序制御則はパケットの到 着間隔分布やサービス時間分布によって異なることに注意する。 AoI の性質はこれらの分布に依って定まるため, 系 2 のように, これらの分布に依存して大小関係が定まる。実際， $\mathrm{E}\left[A_{\mathrm{FIFO}}\right]$ ， $\mathrm{E}\left[A_{\mathrm{LCFS}-\mathrm{P}}\right]$ をそれぞれ先着順サービス, 割込み後着順サービ ス下での平均 AoI としたとき, GI/M/1 の枠組みでは, 常に

$$
\mathrm{E}\left[A_{\mathrm{LCFS}-\mathrm{P}}\right] \leqq \mathrm{E}\left[A_{\mathrm{FIFO}}\right], \quad \mathrm{GI} / \mathrm{M} / 1 \text { の場合 }
$$

が成立する。一方, M/GI/1 の枠組みでは, サービス時間の変 動係数 $\mathrm{Cv}[H]$ やトラヒック強度 $\rho=\lambda \mathrm{E}[H]$ の值が大きい場 合, $\mathrm{E}\left[A_{\mathrm{LCFS}-\mathrm{P}}\right] \leqq \mathrm{E}\left[A_{\mathrm{FIFO}}\right]$ となるため割込み後着順サー ビスが有効であるが，場合によっては先着順サービスの方が小 さな平均 AoI を与えることもある。例えば, サービス時間が 一定の場合に相当する $\mathrm{M} / \mathrm{D} / 1$ の枠組みでは， $\rho^{*} \approx 0.644$ を $2(1-\rho) \exp (\rho)+\rho-2=0(0<\rho<1)$ の唯一根としたとき,

$\mathrm{E}\left[A_{\mathrm{FCFS}}\right] \leqq \mathrm{E}\left[A_{\mathrm{LCFS}}^{\mathrm{P}}\right], \quad \rho \in\left[\rho^{*}, 1\right), \quad \mathrm{M} / \mathrm{D} / 1$ の場合

となる ${ }^{(9)}$. それゆえ，最適な処理順序制御を行うためには，パ ケットの到着間隔分布や処理時間分布に関する情報が不可欠で ある。

\section{7. 関連研 究}

本章では, AoI に関する初期の研究, 並びに以上の章で取り 上げられなかった話題を幾つか紹介する。
近年における AoI 研究の先駆けとなったのが, 車々間アドホッ クネットワーク (VANET: Vehicular Ad Hoc Network) にお けるメッセージング方式に関する研究(1), (11)である。これらの 研究においては平均 AoI の評価にシミュレーションが用いられ ている.文献(2)において, 初めて待ち行列モデルを用いた AoI 過程のモデル化がなされており, 平均 AoI の一般公式 (17) の導 出, 並びに, 先着順サービス $\mathrm{M} / \mathrm{M} / 1, \mathrm{M} / \mathrm{D} / 1$, 及び $\mathrm{D} / \mathrm{M} / 1$ 待ち行列における平均 AoI の解析が行われている.

基本的な処理順序制御のモデルとして, 文献 (6)，(12)におい て割达み後着順サービス及び非割达み後着順サービス $\mathrm{M} / \mathrm{M} / 1$ 待ち行列の平均 AoI が解析されている。 これらの結果は, 文 献 (9)，(13)に押いて, より一般的な到着間隔分布並びにサービ 又時間分布の想定の下, AoI の確率分布の解析へと拡張されて いる. また, 文献(14)，(15)では, 後着順サービスの最適性が, 複数サーバモデル並びにマルチホップネットワークモデルにお いて議論されている.

パケットの追い抜きが発生する通信ネットワークのモデルと して, 文献(16)に扔いて複数サーバ待ち行列 FCFS M/M/2 並 びに $\mathrm{M} / \mathrm{M} / \infty$ の平均 AoI が考察されている. また, 古いパケッ トがサービス機構のバッファに残存することを避けるという観 点から, 待ち行列長やパケットの待ち時間に制限を課すことが 文献 (6)，(17) において提案されている.

文献 (18) （24）では，送信側端末がエネルギーハーベスティ ングにより駆動していると想定し，利用可能なエネルギーに制 約を設けた上で最適なサンプリング間隔制御法が考察されてい る.また, 文献 $(25)$ では, サーバがエネルギーハーベスティン グ端末であるという想定の下, 処理順序制御が議論されている.

複数のアプリケーションがサービス機構を共有する場合, 送信 側端末では他のアプリケーションを意識したサンプリング間隔制 御を行い, サービス機構では各アプリケーションへの適切な資源 割当を行うことが必要となる。送信側端末が自律的にサンプリン グ間隔を決定する状況のモデルとして，文献(26)，(27)におい て, 複数クラス $M / M / 1$ の平均 AoI 並びに複数クラス $M / G / 1$ の平均ピーク AoI が解析され, 更に文献 $(28),(29)$ において, 優先権付き複数クラス $\mathrm{M} / \mathrm{M} / 1$ の平均 AoI が解析されている. また, AoI を指標とした, サービス機構における資源割当問題 は, 文献 (30)〜 (38) に执いて, 主に無線リンクスケジューリン グの文脈で考察されている. 更に, 文献 (39)では, ユーザがモ ニタの表示を参照する時点における AoI の值に注目し, 参照要 求がユーザから到着する夕イミングが確率的に予測可能である という状況下でのスケジューリングが議論されている.

AoI に関する大半の文献では「1パケット」を情報伝送の基 本単位としたモデル化がなされているが，文献 (40)，(41)では, 情報伝送の基本単位を「1 シンボル」としたモデル化を行い, 情 報の符号化方式が平均 AoI に与える影響が考察されている。ま た, 文献 (42)では, ハイブリッド自動再送要求 (HARQ: Hybrid

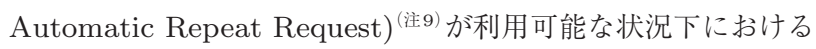
最適な再送制御並びにサンプリング間隔制御が, 平均 AoI を指 標として考察されている。

(注 9）：誤り訂正符号の応用により，再送時の誤り訂正能力を向上させる技術. 
上記に挙げた研究のほかにも, IoT ネットワーク(43), (44), キャッシュサーバ(45), (46), コグニティブ無線 $(47),(48)$, チャネル 干渉のある無線伝送路 ${ }^{(49)}$, CSMA/CA を用いた車々間通信 ${ }^{(50)}$, 時空間相関のある情報源に対する複数センサを用いた観測 (51), 移動中継ノードによる情報拡散及び収集 ${ }^{(52)}$ など, 多様なシステ ムにおけるAoI に関する研究が行われてきている.

\section{8. むすび}

本稿では，AoI の基本概念並びに理論的解析法の基礎を解説 した. AoI は，その定義の単純さから理解できるように，極め て基礎的な概念であり，これからの情報システム設計に抢いて 主要な役割を果たす性能指標であると考えられる。AoI に関す る研究はいまだ黎明期にあり, 年々, 研究論文の発表数が加速 度的に増加している状況である. 本稿をきっかけに，一人でも 多くAoI 研究に興味を持って頂くことができれば幸いに思う.

\section{文献}

(1) S. Kaul, M. Gruteser, V. Rai, and J. Kenney, "Minimizing age of information in vehicular networks," Proc. IEEE SECON 2011, pp. 350-358, 2011.

(2) S. Kaul, R. Yates, and M. Gruteser, "Real-time status: How often should one update?," Proc. IEEE INFOCOM 2012, pp. 2731-2735, 2012.

(3) A. Kosta, N. Pappas, and V. Angelakis, "Age of information: A new concept, metric, and tool," Foundations and Trends in Networking, vol. 12, no. 3, pp. 162-259, 2017.

(4) R. Yates, M. Tavan, Y. Hu, and D. Raychaudhuri, "Timely cloud gaming," Proc. IEEE INFOCOM 2017, 2017.

(5) M. El-Taha and S. Stidham Jr., Sample-Path Analysis of Queueing Systems, Kluwer Academic Publishers, 1999.

(6) M. Costa, M. Codreanu, and A. Ephremides, "On the age of information in status update systems with packet management," IEEE Trans. Inf. Theory, vol. 62, no. 4, pp. 1897-1910, 2016

(7) Y. Sun, Y. Polyanskiy, and E. Uysal-Biyikoglu, "Remote estimation of the Wiener process over a channel with random delay," Proc. IEEE ISIT 2017, pp. 321325, 2017.

(8) Y. Inoue and T. Takine, "AoI perspective on the accuracy of monitoring systems for continuous-time Markovian sources," Proc. The 2nd Age of Information Workshop, 2019.

(9) Y. Inoue, H. Masuyama, T. Takine, and T. Tanaka, "A general formula for the stationary distribution of the age of information and its application to singleserver queues," IEEE Trans. Inf. Theory, to appear, https://doi.org/10.1109/TIT.2019.2938171

(10) Y. Sun, E. Uysal-Biyikoglu, R. Yates, C.M. Koksal, and N.B. Shroff, "Update or wait: How to keep your data fresh," IEEE Trans. Inf. Theory, vol. 63, no. 11, pp. 7492-7508, 2017.

(11) S. Kaul, R. Yates, and M. Gruteser, "On piggybacking in vehicular networks," Proc. IEEE GLOBECOM 2011, 2011.

(12) S. Kaul, R. Yates, and M. Gruteser, "Status updates through queues," Proc. IEEE CISS 2012, 2012.

(13) J.P. Champati, H. Al-Zubaidy, and J. Gross, "On the distribution of AoI for the GI/GI/1/1 and GI/GI/1/2* systems: Exact expressions and bounds," Proc. IEEE
INFOCOM 2019, pp. 37-45, 2019.

(14) A.M. Bedewy, Y. Sun, and N.B. Shroff, "Minimizing the age of information through queues," IEEE Trans. Inf. Theory, vol. 65, no. 8, pp. 5215-5232, 2019.

(15) A.M. Bedewy, Y. Sun, and N.B. Shroff, "The age of information in multihop networks," IEEE/ACM Trans. Netw., vol. 27, no. 3, pp. 1248-1257, 2019.

(16) C. Kam, S. Kompella, G.D. Nguyen, and A. Ephremides, "Effect of message transmission path diversity on status age," IEEE Trans. Inf. Theory, vol. 62, no. 3 , pp. 1360-1374, 2016.

(17) C. Kam, S. Kompella, G.D. Nguyen, J.E. Wieselthier, and A. Ephremides, "On the age of information with packet deadlines," IEEE Trans. Inf. Theory, vol. 64, no. 9, pp. 6419-6428, 2018.

(18) B.T. Bacinoglu, E.T. Ceran, and E. Uysal-Biyikoglu, "Age of information under energy replenishment constraints," Proc. ITA Workshop 2015, pp. 25-31, 2015.

(19) R.D. Yates, "Lazy is timely: Status updates by an energy harvesting source," Proc. IEEE ISIT 2015, pp. 3008-3012, 2015.

(20) A. Arafa and S. Ulukus, "Age-minimal transmission in energy harvesting two-hop networks," Proc. IEEE GLOBECOM 2017, 2017.

(21) B.T. Bacinoglu and E. Uysal-Biyikoglu, "Scheduling status updates to minimize age of information with an energy harvesting sensor," Proc. IEEE ISIT 2017, pp. 1122-1126, 2017.

(22) X. Wu, J. Yang, and J. Wu, "Optimal status update for age of information minimization with an energy harvesting source," IEEE Trans. Green Commun. Netw., vol. 2, no. 1, pp. 193-204, 2018.

(23) A. Arafa, J. Yang, and S. Ulukus, "Age-minimal online policies for energy harvesting sensors with random battery recharges," Proc. IEEE ICC 2018, 2018.

(24) B.T. Bacinoglu, Y. Sun, E. Uysal-Bivikoglu, and V. Mutlu, "Achieving the age-energy tradeoff with a finitebattery energy harvesting source," Proc. IEEE ISIT 2018, pp. 876-880, 2018.

(25) S. Farazi, A.G. Klein, and D.R. Brown, "Age of information in energy harvesting status update systems: When to preempt in service?," Proc. IEEE ISIT 2018, pp. 2436-2440, 2018.

(26) R.D. Yates and S.K. Kaul, "The age of information: Real-time status updating by multiple sources," IEEE Trans. Inf. Theory, vol. 65, no. 3, pp. 1807-1827, 2019.

(27) L. Huang and E. Modiano, "Optimizing age-ofinformation in a multi-class queueing system," Proc. IEEE ISIT 2015, pp. 1681-1685, 2015.

(28) S.K. Kaul and R.D. Yates, "Age of information: Updates with priority," Proc. IEEE ISIT 2018, pp. 2644$2648,2018$.

(29) E. Najm, R. Nasser, and E. Telatar, "Content based status updates," Proc. IEEE ISIT 2018, pp. 2266-2270, 2018.

(30) Q. He, D. Yuan, and A. Ephremides, "On optimal link scheduling with min-max peak age of information in wireless systems," Proc. IEEE ICC 2016, 2016.

(31) Y. Hsu, E. Modiano, and L. Duan, "Age of information: Design and analysis of optimal scheduling algorithms," Proc. IEEE ISIT 2017, pp. 561-565, 2017.

(32) V. Tripathi and S. Moharir, "Age of information in multi-source systems," Proc. IEEE GLOBECOM 2017, 2017.

(33) Y. Hsu, "Age of information: Whittle index for scheduling stochastic arrivals," Proc. IEEE ISIT 2018, pp. 2634-2638, 2018.

(34) Z. Jiang, B. Krishnamachari, S. Zhou, and Z. Niu, "Can decentralized status update achieve universally near-optimal age-of-information in wireless multiaccess channels?," Proc. ITC 30, pp. 144-152, 2018.

(35) Q. He, D. Yuan, and A. Ephremides, "Optimal link 
scheduling for age minimization in wireless systems," IEEE Trans. Inf. Theory, vol. 64, no. 7, pp. 5381-5394, 2018.

(36) I. Kadota, A. Sinha, E. Uysal-Biyikoglu, R. Singh, and E. Modiano, "Scheduling policies for minimizing age of information in broadcast wireless networks," IEEE/ACM Trans. Netw., vol. 26, no. 6, pp. 2637-2650, 2018.

(37) I. Kadota, A. Sinha, and E. Modiano, "Scheduling algorithms for optimizing age of information in wireless networks with throughput constraints," IEEE/ACM Trans. Netw., vol. 27, no. 4, pp. 1359-1372, 2019.

(38) C. Li, S. Li, and Y.T. Hou, "A general model for minimizing age of information at network edge," Proc. IEEE INFOCOM 2019, pp. 118-126, 2019.

(39) B. Yin, S. Zhang, Y. Cheng, L.X. Cai, Z. Jiang, S Zhou, and Z. Niu, "Only those requested count: Proactive scheduling policies for minimizing effective age-ofinformation," Proc. IEEE INFOCOM 2019, pp. 109$117,2019$.

(40) R.D. Yates, E. Najm, E. Soljanin, and J. Zhong, "Timely updates over an erasure channel," Proc. IEEE ISIT 2017, pp. 316-320, 2017.

(41) S. Bhambay, S. Poojary, and P. Parag, "Fixed length differential encoding for real-time status updates," IEEE Trans. Commun., vol. 67, no. 3, pp. 2381-2392, 2019.

(42) E.T. Ceran, D. Gündüz, and A. György, "Average age of information with hybrid ARQ under a resource constraint," IEEE Trans. Wirel. Commun., vol. 18, no. 3, pp. 1900-1913, 2019.

(43) Y. Gu, H. Chen, Y. Zhou, Y. Li, and B. Vucetic, "Timely status update in internet of things monitoring systems: An age-energy tradeoff," IEEE Internet Things J., vol. 6, no. 3, pp. 5324-5335, 2019.

(44) L. Corneo, C. Rohner, and P. Gunningberg, "Age of information-aware scheduling for timely and scalable internet of things applications," Proc. IEEE INFOCOM 2019, pp. 2476-2484, 2019.

(45) R.D. Yates, P. Ciblat, A. Yener, and M. Wigger, "Ageoptimal constrained cache updating," Proc. IEEE ISIT 2017, pp. 141-145, 2017.

(46) J. Zhong, R. Yates, and E. Soljanin, "Two freshness metrics for local cache refresh," Proc. IEEE ISIT 2018, pp. 1924-1928, 2018

(47) A. Kosta, N. Pappas, A. Ephremides, and V. Angelakis, "Age of information and throughput in a shared access network with heterogeneous traffic," Proc. IEEE GLOBECOM 2018, 2018.

(48) S. Leng and A. Yener, "Age of information minimization for an energy harvesting cognitive radio," IEEE Trans. Cogn. Commun. Netw., vol. 5, no. 2, pp. 427439, 2019.

(49) G.D. Nguyen, S. Kompella, C. Kam, J.E. Wieselthier, and A. Ephremides, "Information freshness over an interference channel: A game theoretic view," Proc. IEEE INFOCOM 2018, pp. 908-916, 2018.

(50) A. Baiocchi and I. Turcanu, "A model for the optimization of beacon message age-of-information in a VANET," Proc. ITC 29, pp. 108-116, 2017.

(51) J. Hribar, M. Costa, N. Kaminski, and L.A. DaSilva, "Using correlated information to extend device lifetime," IEEE Internet Things J., vol. 6, no. 2, pp. 24392448,2019

(52) V. Tripathi, R. Talak, and E. Modiano, "Age optimal information gathering and dissemination on graphs," Proc. IEEE INFOCOM 2019, pp. 2422-2430, 2019.

(IT 研究会提案, 2019 年 9 月 5 日受付, 2019 年 10 月 4 日再受付)

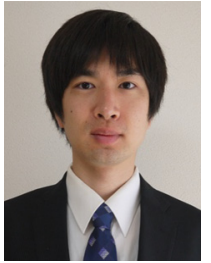

井上文彰 (正員)

平 23 阪大·工・電子情報卒. 平 28 同大学院博 士後期課程了. 同年から現在まで, 阪大大学院工学 研究科電気電子情報工学専攻助教。通信卜ラヒック 工学に関する研究に従事. 博士 (工学). 日本 OR 学 会, IEEE 各会員。

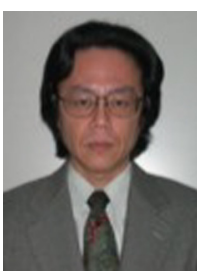

滝根哲哉 (正員)

昭 59 京大.工・数理卒. 平元同大学院博士課程 了. 京大 $\cdot$ 工・助手, 阪大 $\cdot$ 工 講師, 助教授, 京 大大学院情報学研究科助教授を経て, 現在, 阪大大 学院工学研究科電気電子情報工学専攻教授. 通信卜 ラヒック工学に関する研究に従事. 工博. 平 9 日本 OR 学会文献賞, 平 15 , 平 21 電気通信普及財団テ レコムシステム技術賞, 平 15 , 平 20 , 平 25 年度 本会論文賞, 平 18 システム制御情報学会論文賞, 平 23 年度本会通信ソ サイエテイTutorial 論文賞, 同マガジン論文賞, 各受賞. 日本 OR 学会 フェロー, 情報処理学会, システム制御情報学会, IEEE 各会員. 